\title{
Study of Blended Learning Process in Education Context
}

\author{
Asif Irshad Khan ${ }^{1, \mathrm{a}}$, Noor-ul-Qayyum ${ }^{1, \mathrm{~b}}$, Mahaboob Sharief Shaik ${ }^{1, \mathrm{c}}$, Abdullah Maresh Ali ${ }^{1, \mathrm{~d}}$, Ch.Vijaya Bebi ${ }^{2, \mathrm{e}}$ \\ ${ }^{1}$ Faculty of Computing and Information Technology, King Abdul Aziz University, Jeddah, Saudi Arabia \\ ${ }^{2}$ Princeton Degree \& PG College, Osmania University, Hyderabad, India \\ Email: aaikhan@kau.edu.sa, ${ }^{b}$ nulqayyum@kau.edu.sa, ${ }^{c}$ mshaik@kau.edu.sa, ${ }^{\mathrm{d}}$ ammali@kau.edu.sa, \\ ${ }^{\mathrm{e} V i j a y a . c h e t t u p a l l i 3 @ g m a i l . c o m ~}$
}

\begin{abstract}
Education is one of the areas that are experiencing phenomenal changes as a result of the advancement and use of information technology. Mobile and e-learning are already facilitating the teaching and learning experience with the use of latest channels and technologies. Blended learning is a potential outcome of advanced technology based learning system. The charm of blended learning approach lies in the adaptation of technology aided learning methods in addition to the existing traditional based learning. With the introduction of technology, the overall learning as well as teaching experience is considerably enhanced by covering negative aspects of the traditional approach. In this paper a blended learning model for higher education where traditional classroom lectures are supported via e-learning.
\end{abstract}

Index Terms - Blended learning, Assessment, Online learning, Traditional learning

\section{INTRODUCTION}

Blended learning required immediate feedback to the students for their performance which can be achieved by combining assessment technique with the use of latest technological advancement. Blended learning techniques provide teachers to deliver the lecture as well as assess student learning using creative and innovative methods. Assessment is a very vital tool for determining the student's knowledge for the subject they enrolled at any levels of education. Assessment determines how the teacher teaches the course and how student understood the course. Assessment is no doubt one of the major tools in teaching and learning process. In this paper we discussed Blended learning and it's assessment techniques, also, we discussed issues in blended learning environment along with its advantages.

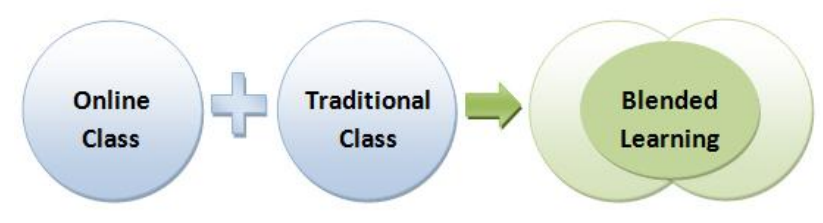

Figure 1 - Blended Learning concept [4]
Blended learning as shown in Figure 1 refers to a learning environment that incorporate diverse teaching styles, delivery means, media formats or a combination of all these [1]. It can also be defined as the integration of various learning activities like online and face-to-face learning [2].

Thanks to the rapid expansion of Internet and increase in bandwidth globally during last two decades, Information Technology has open new horizons for both learner and trainer.

\section{A. e-Learning}

The term e-learning is currently widely accepted for all forms of technology oriented pedagogical methods [3]. Using computer as a communication bridge as well as learning tool is the key aspect of e-learning system.

Blended approach studies how to join the best feature of face to face and online instruction. For example, advanced interactive sessions can be conducted to the students in the classroom while online sessions with multimedia-rich content of the course can be accessed by students anywhere, anytime through internet access.

For a faculty it is important to be familiar with the state of art of assessment methodologies along with its cons and pros to incorporate the latest assessment methodology or tool in their teaching and assessment technique in an organized and efficient manner.

\section{B. Assessment}

Assessment is considered as an effective tool in determining student's knowledge gain in a particular course they enrolled. There are different ways of assessment, some are formal and some are informal. Under formal assessment category a teacher usually assess student's knowledge for the course using quizzes, practical exam, test, viva, projects, home assignments and examinations.

These formal assessment activities are helpful for a teacher to know the teaching and learning progress for assigning grades for a course. Under informal assessment category a teacher usually assess student's using variety of technique like pop-up questions during lecture, class discussion, other activities in the class like punctuality 
and sincerity. These informal assessments help teacher to know more about what and how students are learning and progressing, also, it further helps teacher to get useful feedback on his teaching-learning process and for his students too.

The paper is organized as follows: sections II covers literature review, section III compared blended learning with traditional learning, section IV highlighted some of the advantages of blended learning, section $\mathrm{V}$ point out the process of assessment in blended learning, section VI mentioned some of the challenges of blended learning, section VII described our proposed model and conclusion of the paper is covered in section VIII.

\section{LITERATURE REVIEW}

The value of learning process should be judge by employing various assessment methods, tools and techniques so as to support and improve blended learning [5].

\section{A. Assessment in blended learning}

Ma Xiufang and Ke Qingchao [5] proposed a framework of assessment design from the prospective of assessment principles, factors, process, method and tools of blended learning and provide the corresponding design templates.

\section{B. Students' views on blended learning}

Banci and Soren [6] believed level of education quality can be improved when combined two approaches in an organized and balanced manner, and it should not be considered as creating a new education method by combining different education.

The results of their study conducted on 64 students showed that the students enjoyed taking part in the blended learning environment. Students' achievement levels and their frequency of participation to forum affected their views about blended learning environment. Face-to-face interaction in blended learning application had the highest score. This result demonstrated the importance of interaction and communication for the success of on-line learning.

\section{Academic achievements in a blended learning}

Betül Y1lmaz and Feza Orhan [7] conducted an extensive survey to find student's academic achievement by introducing blended learning technique in the 'Instructional Technologies and Material Development' course. The results showed that; blended learning environment has a positive effect on academic achievements; using Web based learning environments regularly and attendance to learning environments for both deep and surface learners.

Based on the study results Betül Yilmaz and Feza Orhan [7] recommended blend face to face courses with Web based learning to achieve efficient learning environments [7]. Clark and Meyer [8] see blended learning as an education models which have a capabilities of having best features from every sort of technology.

To know the effectiveness in terms of student motivation and achievement Ünsal [9] compared blended and face-to-face learning environments. In the experiment both environments were setup, results showed e-learning environment played a vital role in access individual studies, supplement learning, and progressing at one's own pace, while there was no major different in blended and face-to-face learning approaches in terms of academic achievement and students' motivation scores [9].

\section{Task-Based Learning}

In this study, Kirkgoz [10] investigates designing and implementing a speaking course in which face-to-face instruction informed by the principles of Task-Based Learning is blended with the use of technology. Results of this study revealed that students made noticeable improvement in their oral communication skills, and they were positive in their perceptions of integrating technology in the lesson.

\section{E. Pan European Initiative}

The purpose of this Pan European initiative project [11] is to create an innovative international learning resource that could be widely accessible to construction management professionals thereby facilitating improved knowledge and skills within the industry.

This project is focused on the management of the learning experience, through implementing wellestablished pedagogical practices when integrating technology as part of the delivery of learning. This research project is based on the assumption that technology can be matched to meet individual learning styles as part of a blended learning program.

\section{COMPARISON BETWEEN TRADITIONAL LEARNING AND BLENDED LEARNING}

The difference between Traditional learning and Blended Learning is highlighted in Table I. Traditional learning is more class oriented and less flexible in terms of class schedule, use of latest technology and learning methodology while blended Learning is flexible and support both class room as well as online teaching.

TABLE I.

COMPARISON BETWEEN TRADITIONAL LEARNING AND BLENDED LEARNING

\begin{tabular}{|l|l|l|}
\hline $\begin{array}{l}\text { Characteristic } \\
\text { of learning }\end{array}$ & $\begin{array}{l}\text { Traditional } \\
\text { learning }\end{array}$ & $\begin{array}{l}\text { Blended } \\
\text { Learning }\end{array}$ \\
\hline Place & $\begin{array}{l}\text { Mainly in } \\
\text { classrooms (Not } \\
\text { flexible) }\end{array}$ & $\begin{array}{l}\text { Combination } \\
\text { of classroom / } \\
\text { home, library } \\
\text { (flexible) }\end{array}$ \\
\hline
\end{tabular}




\begin{tabular}{|l|l|l|}
\hline $\begin{array}{l}\text { Learning } \\
\text { Methodology }\end{array}$ & $\begin{array}{l}\text { Offline as well } \\
\text { as Online } \\
\text { Learning }\end{array}$ \\
\hline $\begin{array}{l}\text { Time of } \\
\text { learning }\end{array}$ & $\begin{array}{l}\text { Fixed as per the } \\
\text { schedule (Not } \\
\text { flexible) }\end{array}$ & $\begin{array}{l}\text { Adjustable as } \\
\text { per personal } \\
\text { choice } \\
\text { (Flexible) }\end{array}$ \\
\hline $\begin{array}{l}\text { Use of } \\
\text { Technology }\end{array}$ & $\begin{array}{l}\text { Not must up to } \\
\text { the instructor to } \\
\text { choose the } \\
\text { teaching } \\
\text { methodology. }\end{array}$ & $\begin{array}{l}\text { Latest use of } \\
\text { technology is } \\
\text { must. }\end{array}$ \\
\hline
\end{tabular}

\section{Advantages of Blended LeARning}

Blended learning integrates online and offline learning activities and resources to reduce in-class seat time for students in a face-to-face environment which make it a tremendous advantage for a university. It can help the university management to enhance under-enrolled programs, complete faculty teaching loads, and improve cost effectiveness. Blended learning facilitates students with a unique flexible learning experience, because they can access and engage with their educational program from anywhere and at any time. The participants did not need to be on the campus to actively engage in their studies.

Following is the list of advantages of using blended learning technique in an education system.

- Blended learning environment provides many resources of learning to learner which enhanced learner's confidence and competency.

- Quick feedback to learner which will help them in their learning process.

- Remove the constraints of traditional training and learners decide where and when they do their training

- Learners more responsible for their training and help them be self-motivated.

- Blended learning provide Collaborative activities among teacher and students through interactive session which will helps to improve the students level of satisfaction and Improved academic performance.

- Provide access to everyone who needs training by providing it in different ways.

\section{BLENDED ASSESSMENT}

E-assessment, digital assessment, mobile based examination and online assessment are some of other term used in education system for Blended assessment. Teacher creativity and innovation in setting the assessment paper result in fruitful feedback to the learner. Specific benefits of blended assessment include [12]:
- Students will be highly motivated as feedback or their assessment is available in a short period.

- Students become critical thinker with the supports inquiry-based learning.

- Faculty gets the immediate and complex student feedback.

- Faculty focused on high level activities such as critical thinking, assessment analysis instead of low value, manual tasks;

- Faculty can improve their professional development through critical analysis of availability of student assessment data.

- Blended assessment produced an environment of collective learning excellence with the availability of authentic results for both students and faculty.

\section{Challenges When Blending}

The challenges of blended learning are not entirely unique to blended learning. Culture, technology, infrastructure, and skills are challenges faced by learning professionals in general. Blended learning is not easy to adopt. Developing learning staff knowledge and skills, learning authority, funding, sufficient technology support and infrastructure, administration, resources and change management all have to be addressed to overcome the challenges associated with blended learning. There are many reasons that an instructor or learner might pick blended learning over other learning options. There are six major issues that are relevant to designing blended learning systems [13]:

1. How to create interactive blending environment and assign the roles of live interaction, so as to have interactive learning process to achieve learner satisfaction with the process.

2. The role of learner choice and self-regulation mainly focuses on how different blends might affect student's learning experience.

3. How to propose a common hybrid model that support and training so as to get successful blended approach to learning from the technological as well as infrastructure / organizational perspective.

4. Finding balance between innovation and production, Designing blended learning systems is changeling since, technology is relatively changing, and finding an appropriate balance between innovation and production is difficult.

5. Cultural adaptation, and

6. Dealing with the digital divide.

\section{BLENDED LEARNING MODEL FOR HIGHER EDUCATION}

Our proposed blended learning model is based on student's self-learning at home. This section describes a 
learning process model for designing and developing a blended course for higher education.

Our blended learning model is based on self-learning through e-Learning and face-to-face classes. We propose a blended learning process model as shown in Figure 2 as a reference model for constructing the learning environment.

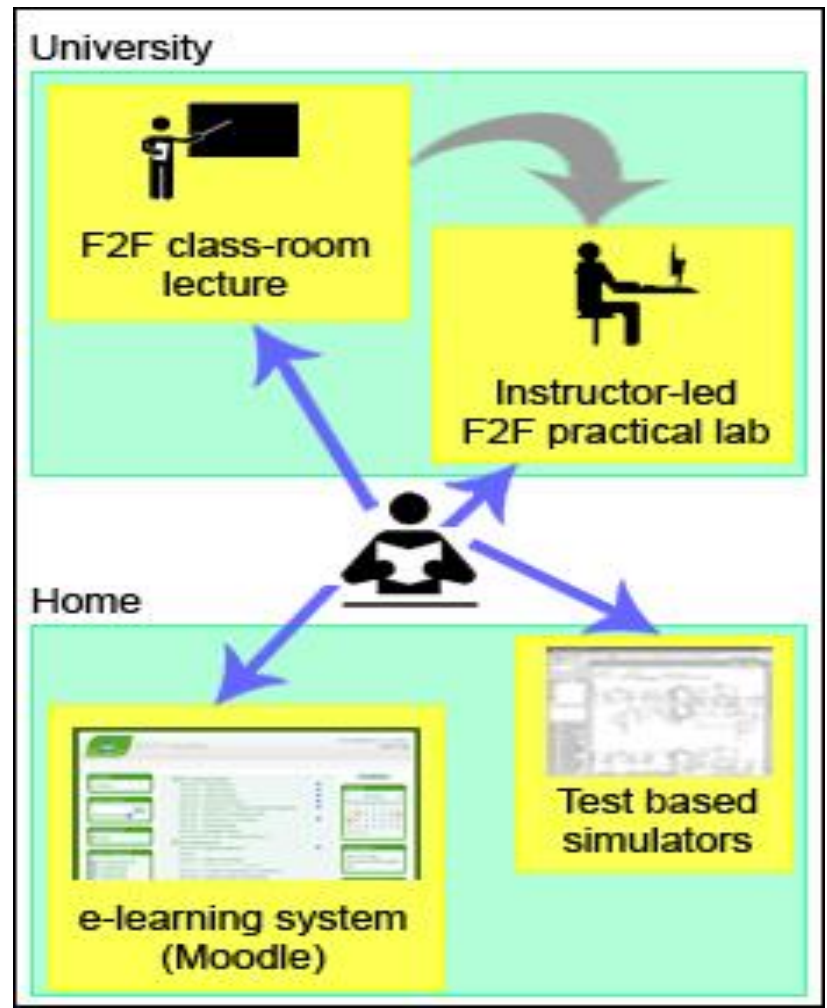

Figure 2- Blended Learning process

The blended learning style course based on our proposed model has the following four characteristics:

1. Students can study basic course in Face-to-Face (F2F) lecture at university.

2. Students can implement the practical part of lecture in the lab.

3. Instructor can give lecture and additional learning contents via e-Learning environment.

4. The practical part of the lecture can be simulated and available via e-Learning environment.

In this blended based course, the instructor can also check whether students prepare and review by e-
Learning, self-tests, simulators and the result of selftests.

\section{A. Design of course contents}

The design of learning contents includes the basic course plan and proportion of class theory and lab practical. It also includes the duration of each module, designing tests, and home assignments. The purpose of the learning process designed to strengthen the predictability of the learning process.

\section{B. Design of e-leaning contents}

Ally [14] argued that e-learning designers should select learning strategies that motivate learners, facilitate deep processing, build the whole person, cater for individual differences, promote meaningful learning, encourage interaction, provide feedback, facilitate contextual learning, and provide support during the learning process. We used open source LMS, moodle [15] to host eLearning contents as shown in Figure 3, 4 and 5. The process of authoring courseware for moodle includes the development of learning materials (weekly lectures and tests), adaptation rules and other content such as student discussion groups and forums.

To use moodle e-learning environment as shown in Figure 3, 4 and 5, a student must first log on. After authorization, the student has to choose the subject they wishes to learn, or a course. The course consists of modules and each module contains several lessons and tests. The online test contains problem-based questions such as essay-type assignments, MCQs and programming assignments.

\section{Assessment}

Assessment is one of the most critical ingredients of blended learning [16][17], for two reasons: 1) It enables learners to "test out" of content they already know, finetuning their own blended learning experience, and 2) It measures the effectiveness of all other learning modalities and events. At the end of the course an assessment of the students was conducted. The purpose of the assessment is to find out their academic progress as well as to what extent the students were accepting the learning model based on the blended learning strategy that integrates self-learning via online e-learning environment and classroom environment. 

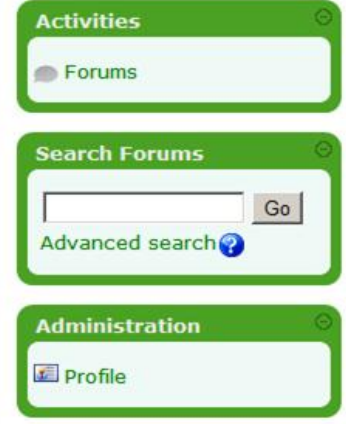

Course categories
$\square$ FCIT Requirements
$\square$ CS-Department
$\square$ IS-Department
IT-nannrtmnnt

$\Theta$ FCIT Requirements CPCS 202 - Programming I CPCS 203 - Programming II CPCS 204 - Data Structures I CPCS 222 - Discrete Structures I

CPIS 334 - Introduction To Software Project Management CPIS 428 - Professional Computing Issues CPIT 201 - Introduction To Computing CPIT 221 - Tichnical Writing STAT 210 - Probability Theory CPIT-CPIS-CPCS 498 - Graduation Project 1

GS-Department CPCS473- Computer Networks 3 CS 652

CPCS 211 - Digital Logic Design

CPCS 212 - Applied Math for Computing 1

CPCS 214 - Computer Organization \& Architecture

\section{Turn editing on}

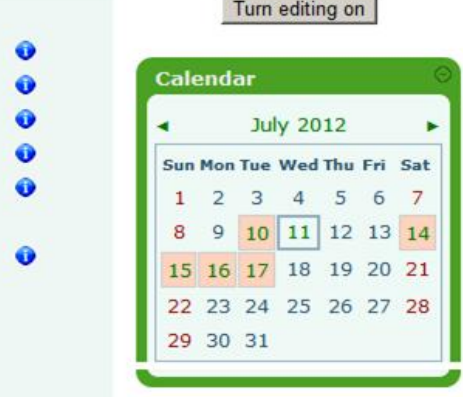

(1)

\section{Latest News}

Add a new topic...

(No news has been posted yet)

Figure 3- Online Courses available on Moodle [15]

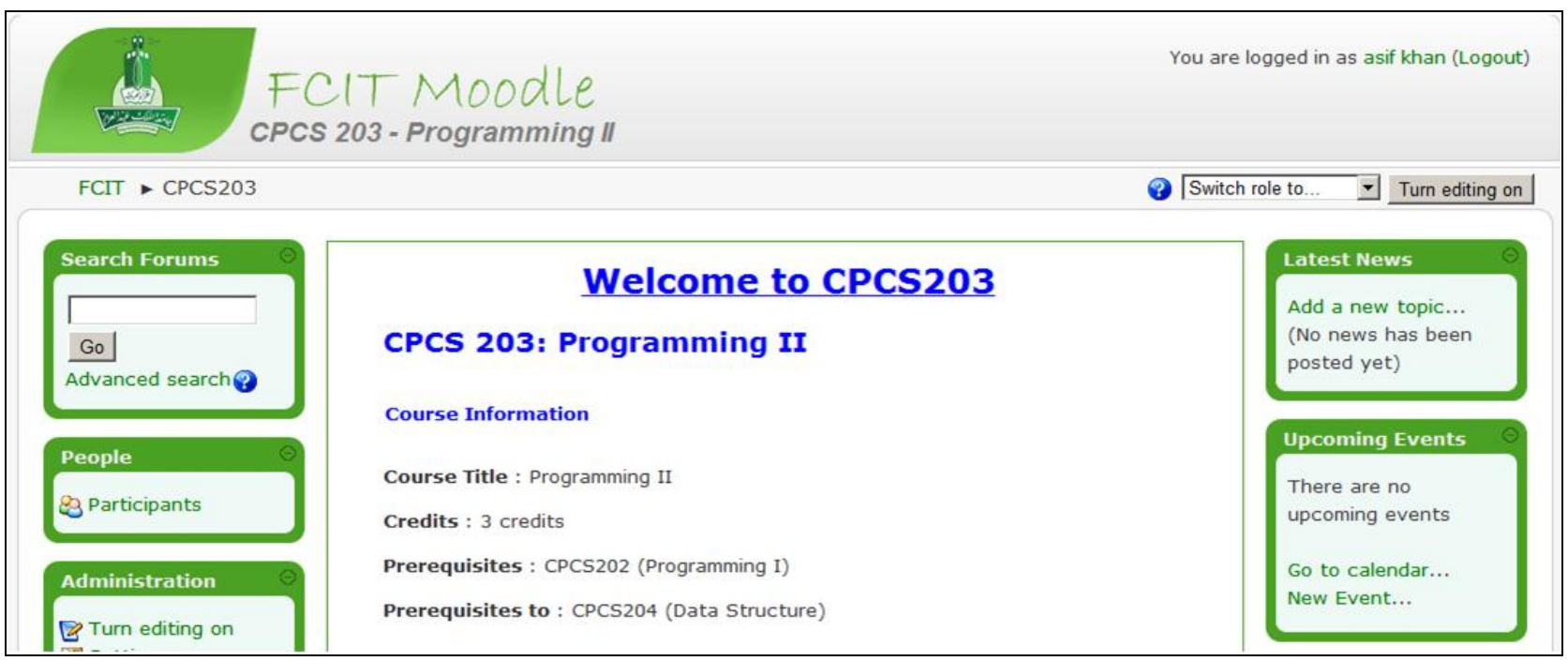

Figure 4- Online Course detail for course Programming-II [15]

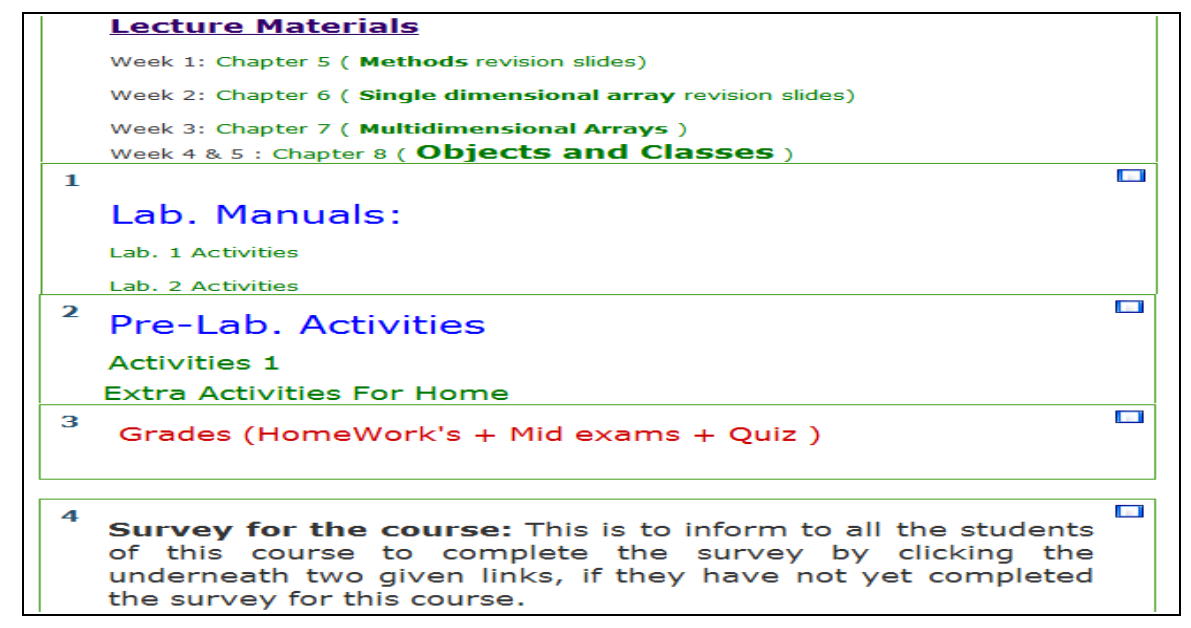

Figure 5- Online Course detail for course Programming-II [15] 


\section{CONCLUSION}

Blended learning supports more flexible, interactive, efficient, accessible, and varied learning experience for both teacher and their students. The charm of blended learning approach lies in the adaptation of technology aided learning methods in addition to the existing traditional based learning. Assessment is a very vital tool for determining the student's knowledge for the subject they enrolled at any levels of education. Blended learning techniques provide teaches to delivered the lecture as well as assess student learning using creative and innovative methods. In this paper we study blended learning process the list of advantages of using blended learning technique in an education system. The paper also discuss about the assessment method to be considered in this learning techniques, Issues in blending learning is also discussed in this paper. In future we will study blended learning perspective at King Abdul Aziz University.

\section{REFERENCES}

[1] Morgan. K. R. (2002). Blended Learning: A Strategic Action Plan for a New Campus. Seminole, FL: University of Central Florida.

[2] Reay, J. (2001). Blended learning - a fusion for the future. Knowledge Management Review, 4(3), 6.

[3] D. Del Corso, E. Ovcin, and G. Morrone, "An instructor friendly environment to foster learnercentered customization in the development of interactive educational packages," IEEE Trans. Educ., vol. 48, no. 4, pp. 574-579, Nov. 2005.

[4] Maryam Tayebinik , Marlia Puteh , Blended Learning or E-learning? IMACST: vol. 3 no. 1 Feburay 2012

[5] Ma Xiufang, Ke Qingchao, "Assessment in Blended Learning: A Framework for Design and Implementation," csse, vol. 5, pp.598-601, 2008 International Conference on Computer Science and Software Engineering, 2008.

[6] Banci M \& Soren H. (2008). Students' opinion on blended learning. Turkish Online Journal of Distance Education, 10(1), 21-35.

[7] M. Betül Yılmaz, Feza Orhan, "Evaluation of university students' academic achievements, web material using behaviors, and attendances in respect to their learning approaches in a blended learning environment", vol. 8, no 2, pp. 1027-1048. International Journal of Human Sciences, 2011.

[8] Clark, R. T. \& Meyer, R. E. (2003). E-learning and the science of instruction. San Francisco, CA: Preiffer Publishing.

[9] Ünsal H, Multi-Level Evaluation of the Effectiveness of Blended Learning. Unpublished Doctorate Dissertation, Ankara: Gazi University, Graduate School of Eigitim, 2007.
[10] Kirkgoz, Y "A Blended Learning Study on Implementing Video Recorded Speaking Tasks in Task-Based Classroom Instruction", vol 10, No. 4, pp. 1 - 13, The Turkish Online Journal of Educational Technology - October 2011.

[11] Wall, J., Ahmed, V., HURST, A., Garrecht, H., Luckey, A., Macnamee, F. and Kanoglu, A., 2006. A pan-European initiative to formulate a framework for blended learning targeting continuing professional development in the construction industry. In: 10th World Conference on Continuing Engineering Education, Vienna, 2006.

[12] Graham, C. R., Allen, S., \& Ure, D. (2005). Benefits and challenges of blended learning environments. In M. Khosrow-Pour (Ed.), Encyclopedia of information science and technology (pp. 253-259). Hershey, PA: Idea Group.

[13] M. Betül Yılmaz, Feza Orhan, International Journal of Human sciences, Vol 8, No 2 (2011)

[14] Ally, M. (2004). Foundations of educational theory for online learning. In T. Anderson \& F. Elloumi (Eds.), Theory and practice of online learning. Athabasca, Canada: Creative Commons: Athabasca University.

[15] Moodle, Faculty of Computing and Information Technology, King Abdul-Aziz University, Jeddah Retrieved from http://fcit.kau.edu.sa

[16] Carman, J. M. (2005). Blended learning design: Five key ingredients. Retrieved from http://www.agilantlearning.com/pdf/Blended\%20Lea rning\%20Design.pdf

[17] Blended Assessment: Authentic Technology Driven Strategies in Student Assessment, Linda C. Orozco, Anais do Fórum International - ISSN: 2238-0027, 2012

\section{AUTHORS BIOGRAPHY}

Mr. Asif Irshad Khan received his Bachelor and Master degree in Computer Science from the Aligarh Muslim University (A.M.U), Aligarh, India in 1998 and 2001 respectively. $\mathrm{He}$ is presently working as a Lecturer Computer Science at the Faculty of Computing and Information Technology, King Abdul Aziz University, Jeddah, Saudi Arabia. He has more than seven years experience of teaching as lecturer to graduate and undergraduate students in different universities and worked for four years in industry before joining academia full time. He has eleven research publications in national and International Journals and his research interest includes Software Engineering, mainly Component Based Software Engineering (CBSE) and Agent Oriented Software Engineering (AOSE). 
Mr. Noor-ul-Qayyum received his Master degree in Information Technology from National University of Sciences and Technology, Islamabad, Pakistan in 2009. He had been working for Ikonami Technologies and Decker Intellectual Properties as a software engineer before joining King Abdul Aziz University. He is currently working as a lecturer in King Abdul Aziz University. He has industry experience in SCORM based e-learning courseware development using ADDIE model. His research interest includes e-learning, software watermarking, and mobile agent security issues.

Mr. Mahaboob Sharief Shaik received his Bachelor and Master degree in Computer Science from the Osmania University, India. He is presently working as a Lecturer Computer Science at the Faculty of Computing and Information Technology, King Abdul Aziz University, Jeddah, Saudi Arabia. He has more than ten years experience of teaching as lecturer to graduate and undergraduate students in different universities. His area of research interest is Database and Information security.

Mr. Abdullah Maresh Ali received his Master degree in Computer Science from King Abdul Aziz University, Jeddah, Saudi Arabia in 2011. He is presently working as a Lecturer Computer Science at the Faculty of Computing and Information Technology, King Abdul Aziz University, Jeddah, Saudi Arabia. His research interest includes Computer networks and Agent Oriented Software Engineering.

Ch. Vijaya Bebi received Master of Computer Application from Sree Padmavathi Mahila University, in the year 2011 and presently working as programmer in Princeton Degree and PG College, Osmania University, Hyderabad, India. 